\title{
Erratum to: Copper diffusion in cable-insulating materials by chemiluminescence and DSC techniques
}

\author{
Silviu Jipa ${ }^{1}$ Radu Setnescu ${ }^{1,2} \cdot$ Traian Zaharescu $^{2} \cdot$ Tanta Setnescu $^{1,2}$. \\ Laura Monica Gorghiu ${ }^{1}$ Iulian Băncuţă $\breve{3}^{3}$ Elena Daniela Chelărescu ${ }^{4,5}$
}

Received: 24 January 2016/ Accepted: 24 January 2016/Published online: 13 February 2016

(C) Akadémiai Kiadó, Budapest, Hungary 2016

\section{Erratum to: J Therm Anal Calorim (2015) 122:251-259 \\ DOI 10.1007/s10973-015-4668-z}

The correct Acknowledgements are as follows:

\begin{abstract}
Acknowledgements This work was financed by the Romanian Ministry of National Education-Executive Unit for Financing Higher Education, Research, Development and Innovation (MENUEFISCDI) - through the PN II 2013 Partnerships Programme, Project 262/2014, "High performance polymeric insulations for electrical rotation machines. Technology and modeling approaches".
\end{abstract}

The online version of the original article can be found under doi:10.1007/s10973-015-4668-z.

Radu Setnescu

rsetnescu@yahoo.com

$\triangle$ Traian Zaharescu

traian_zaharescu@yahoo.com

1 Faculty of Science and Arts, Valahia University of Târgovişte, Bd. Unirii 18-22, 130082 Târgovişte, Romania

2 Department for Advanced Materials, National R\&D Institute for Electrical Engineering (INCDIE ICPE-CA), Splaiul Unirii 313, Sector 3, 030138 Bucharest, Romania

3 Multidisciplinary Research Institute for Science and Technologies (UVT-ICSTM), Valahia University of Târgovişte, Bd. Unirii 18-22, 130082 Târgovişte, Romania

4 National R\&D Institute for Physics and Engineering, Măgurele, Romania

5 Faculty of Physics - Doctoral School, University of Bucharest, Bucharest, Romania 